\title{
The Influence of Brand Story Types on Consumers' Brand Attitude
}

\begin{abstract}
$\mathrm{Yu} \mathrm{Xie} \mathrm{*}$
Beijing Jiaotong University. China

${ }^{*}$ Corresponding author. Email: 15868066229@163.com

ABSTRACT

Brands play a key role in corporate competition. The emergence of brand stories helps build brands and enhance brand value. In addition, as a crucial way and channel for brands to communicate with consumers, brand stories have increasingly become an important means for companies to shape their competitive advantages.

To explore the impact of brand stories of different manifestations (fictional brand stories, factual brand stories) on the consumer's brand attitudes, this study takes the type of brand story as the independent variable, and brand attitude as the dependent variable, mainly using experimental methods for research, designing single-factor two-level intra-group experiments, and using SPSS to analysis data. Finally, it is concluded that brand stories in different manifestations have significantly different effects on brand attitudes.
\end{abstract}

Keywords: Brand story, Brand attitude, Story type.

\section{INTRODUCE}

\subsection{Background}

With the advancement of science and technology and the development of the Internet, the scale of the market has grown unprecedentedly, and competition among enterprises has become increasingly fierce. In brand marketing, a good brand story can give a brand personality and convey brand value.

Literally, a brand story is a combination of a brand and a story, with brand history, brand culture, brand products, etc. as the background of the story. Researching brand stories from different angles, scholars have put forward different meanings. Yang Dajun (2005) regards the brand story as another form of advertisement, which realizes the successful emotional transmission between the brand and consumers in the process of brand development. Yuan Shaogen (2005), Wang Tao (2011) and others proposed that brand stories are brand narratives. Companies use relevant news articles, advertisements, public relations activities and cultural communication activities to convey the brand connotation in the form of storytelling, which vividly reflects interest appeal points of service and product, and delivers corporate background culture and brand core value concepts, etc. Allen (2013) et al. equated brand stories with narratives, telling and depicting the heart and soul of the brand, linking the information and emotions between the brand and consumers. It can be seen from these that we can understand the brand story as a way of narrating through storytelling, conveying brand information, brand background culture, brand core values and other content to consumers, so that consumers can identify with the brand and establish a brand with consumers Emotional communication and connection between.

In addition, the consumer's brand attitude takes the consumer as the main body and the brand as the object. It is defined as the overall positive or negative evaluation of the brand and the strength of evaluation after consumers accept certain brand information. Arjum (1999) proposed that brand attitude is a positive or negative evaluation and intensity evaluation of the brand formed by consumers after receiving various brand-related stimuli. Sengupta and Fitzismon (2000) believe that brand attitude is the psychological internal evaluation of the brand formed by the purchase decision maker based on past experience and the information obtained after receiving the stimulation of the brand attribute-related information. The perception of emotional elements ultimately affects consumer behavior.

By consulting a large number of relevant references, it can be found that many scholars have conducted in- 
depth research on brands, narratives, and brand attitudes, exploring their concepts, theories, measurement methods, and influencing factors. However, the research on the types of brand stories is poor, and the research scope also has certain limitations.

At present, scholars mostly classify brand stories according to the theme, object, content, etc. of brand stories, in order to explore the influence of brand story types on brand attitudes. Jia Yanrui sorted out and analyzed the classification basis of brand stories, and proposed the enlightenment of dividing brand stories into factual brand stories and fictional brand stories according to the manifestations of story content. Factual brand story, also known as legendary story or brand biography, refers to a biographical brand story, which selectively records the origin, experience, and changes of the brand in chronological order (Jill Avery et al., 2010), thus narrating unfold. The factual brand story transforms the static brand personality to the dynamic brand personality, conveying a brand connotation that is selectively narrated by the company, in order to influence consumers' associations and preferences for the brand. Fictional brand story is the opposite, advertising is one of it. There are few studies on the mechanism of its influence on brand attitudes. In addition, Hovland and Rosenberg (1953) proposed the attitude ABC model, which includes the threedimensionality of Affective component, Behavioral component and Cognitive component.

Previous studies have put forward the following conclusions. Brand story has a positive effect on brand attitude (Xie Yi, 2012). Brand stories can enhance consumers' perceptions of functional, experiential and symbolic brand image (Wang Jiawei, 2005). The brand story is conducive to building and enhancing the brand, making consumers feel recognized and moved, helping the brand to form a stable and intimate relationship with consumers, so as to strengthen the brand loyalty of consumers (Huang Guangyu, 2006). Compared with fictional plots, the true plots of brand stories are more likely to improve the fluency of the audience's selfimagination, and thus it is easier to improve the brand attitude of the story audiences (Xu Lan, 2020).

\subsection{Hypotheses}

Inspired by the above research, this research divides brand stories into factual brand stories and fictional brand stories according to the manifestations of stories, and divides brand attitudes into three dimensions: cognition, emotion, and behaviour tendency. Taking the type of brand story as the independent variable, and brand attitude as the dependent variable, this research explores the impact of different types of brand stories on brand attitude and its mechanism, and puts forward the following hypotheses:
H1: Fictional brand stories and factual brand stories have significantly different effects on brand attitudes.

H1a: Fictional brand stories and factual brand stories both have a significant impact on the cognitive dimension of brand attitudes.

H1b: Fictional brand stories and factual brand stories both have a significant impact on the emotional dimension of brand attitudes.

H1c: Fictional brand stories and factual brand stories both have a significant impact on the dimension of behaviour tendency brand attitudes.

\section{METHOD}

\subsection{Experiment}

This research mainly uses questionnaire-style situational experiment method, adopts single factor twolevel in-group experimental design, and takes manifestation of brand story (fictional brand story, factual brand story) as the group variable.

In order to prevent the participants from affecting the measurement results of the original knowledge, perception, and attitude of the existing brand, this experiment uses a virtual brand, and the product is sports shoes. Scenario 1 provides basic information and fictional brand story of brand $\mathrm{A}$, and scenario 2 provides basic information and factual brand story of brand B. Both brand stories are in the form of text, which aims to highlight the characteristics of good product quality and have the same text length, description style, etc.

The questionnaire has four parts in total: The first part introduces the identity of the researcher, the theme and the purpose of the research, and informs the experimental background. The second part gives two scenarios and invites participants to fill in a measurement scale for brand story types and brand attitudes. The third part asks the basic information of the participants, including gender, age, and educational background. The questionnaire is distributed online.

Before the formal experiment, in order to ensure that the theme and method of the brand story perceived by the participants were in line with the assumptions, this study pre-tested in a small-scale on three consumers, and the results were all in line with expectations.

\subsection{Variable Measurement (Table 1)}

Research on the scale of brand attitude began in the last century so that the results are relatively mature. This study uses the three-dimensional measurement items of cognitive, emotional, and behaviour tendency compiled by $\mathrm{Xu}$ Man scholar (2020) based on the research of Bagozzi et al. (2001), Zhou Wenhui and Yang Jin (2008) and Jia Yanrui (2017) to measure brand attitudes. 
Table 1. Measuring scale of brand attitude

\begin{tabular}{|c|c|c|}
\hline Concept & Dimension & Measurement item \\
\hline \multirow{11}{*}{$\begin{array}{l}\text { Brand } \\
\text { attitude }\end{array}$} & \multirow{3}{*}{$\begin{array}{l}\text { Dimension of } \\
\text { Cognition }\end{array}$} & 1.The story deepened my image of the brand and made me more familiar with the brand. \\
\hline & & $\begin{array}{l}\text { 2.The story enabled me to understand or perceive more brand information, such as brand core values, } \\
\text { brand positioning, etc. }\end{array}$ \\
\hline & & $\begin{array}{l}\text { 3.The story made me understand the brand's product information, such as product usage scenarios, } \\
\text { product features, etc. }\end{array}$ \\
\hline & \multirow{3}{*}{$\begin{array}{c}\text { Dimension of } \\
\text { Emotion }\end{array}$} & 4.The story increased my goodwill towards the brand and made me like it even more. \\
\hline & & 5.This story brought me closer to the brand and made people feel more cordial. \\
\hline & & 6.The story increased my recognition of the brand, and I trusted the brand even more. \\
\hline & \multirow{5}{*}{$\begin{array}{c}\text { Dimension of } \\
\text { Behavior } \\
\text { Tendency }\end{array}$} & 7.After reading this story, I will give priority to this brand product among similar products. \\
\hline & & 8.After reading the story, I am willing to pay a higher price to buy the brand's products. \\
\hline & & 9.After reading the story, I am more likely to buy the brand's products. \\
\hline & & 10.I will discuss or recommend the brand's products to my family and friends. \\
\hline & & $\begin{array}{l}\text { 11.I am willing to participate in activities related to the brand (such as joining an online brand } \\
\text { community, commenting on the brand, etc.). }\end{array}$ \\
\hline
\end{tabular}

\section{RESEARCH RESULTS}

\subsection{Descriptive Statistics}

In this study, a total of 200 valid data were recovered through online channels. There are many female samples, accounting for 58\%. The samples are distributed in various age groups, with the majority being 20-25 years old, accounting for 44\%. Among them, the "undergraduate" degree samples accounted for $61.5 \%$, which is the main group.

\subsection{Reliability Analysis}

In this study, the same questionnaire was used to measure consumer brand attitudes in two scenarios, and 11 items were set in each scenario, including three dimensions of cognition, emotion, and behaviour tendency. In the context of a fictional brand story, the reliability $\alpha$ coefficient of the cognitive dimension is 0.899 , the reliability $\alpha$ coefficient of the emotional dimension is 0.858 , and the reliability $\alpha$ coefficient of the dimension of behaviour tendency is 0.876 . In the context of a factual brand story, the reliability $\alpha$ coefficient of the cognitive dimension is 0.841 , the reliability $\alpha$ coefficient of the affective dimension is 0.818 , and the reliability $\alpha$ coefficient of the dimension of behaviour tendency is 0.782 . This shows that the internal consistency of the scale is very high.

\subsection{Validity Analysis}

\subsubsection{KMO and Bartlett Test}

KMO and Bartlett tests were performed on the brand attitude scale data. The measured value of the KMO sample is 0.836 , the approximate chi-square value of the Bartlett test is 1939.374, and the significance is 0.000 , which passed the significance test with a significance level of $1 \%$. It can be seen from the data that the scale data is very suitable for factor analysis.

\subsubsection{Extraction of Principal Components} (Table 2)

By extracting the principal components, it can be known that the cumulative explained variance of component 1 , component 2 , and component 3 is $70.367 \%$. It shows that the three factors extracted are ideal for the interpretation of the original data.

\subsubsection{Rotating Component Matrix (Table 3)}

Judge the attribution of the factors of each topic according to the matrix of rotating components. XWQX2, XWQX5, XWQX1, XWQX4, XWQX3 belong to factor 1, which is named "behaviour tendency". RZ2, RZ3, and RZ1 belong to factor 2, which is named "cognition". QG1, QG3, and QG2 belong to factor 3 , which is named "emotion". 
Table 2. Explanation of total varianceComponents

\begin{tabular}{|c|c|c|c|c|c|c|c|c|c|}
\hline & \multicolumn{3}{|c|}{ Initial eigenvalue } & \multicolumn{3}{|c|}{ Extract the sum of squares of the loads } & \multicolumn{3}{|c|}{ Sum of squares of rotating loads } \\
\hline & Sum & $\%$ Variance & Cumulative $\%$ & Sum & $\%$ Variance & Cumulative\% & Sum & $\%$ Variance & Cumulative\% \\
\hline 1 & 4.310 & 39,182 & 39.182 & 4.310 & 39.182 & 39.182 & 3.031 & 27.558 & 27.558 \\
\hline 2 & 1.861 & 16.922 & 56.104 & 1.861 & 16.922 & 56.104 & 2.401 & 21.831 & 49.389 \\
\hline 3 & 1.569 & 14.263 & 70.367 & 1.569 & 14.263 & 70.367 & 2.308 & 20.978 & 70.367 \\
\hline 4 & 0.592 & 5.384 & 75.751 & & & & & & \\
\hline 5 & 0.511 & 4.642 & 80.393 & & & & & & \\
\hline 6 & 0.461 & 4.188 & 84.581 & & & & & & \\
\hline 7 & 0.443 & 4.025 & 88.606 & & & & & & \\
\hline 8 & 0.360 & 3.276 & 91.882 & & & & & & \\
\hline 9 & 0.325 & 2.957 & 94.838 & & & & & & \\
\hline 10 & 0.291 & 2.647 & 97.486 & & & & & & \\
\hline 11 & 0.277 & 2.514 & 100 & & & & & & \\
\hline
\end{tabular}

Table 3. Component matrix after rotation

\begin{tabular}{|c|c|c|c|}
\hline \multirow{2}{*}{ Topic } & \multicolumn{3}{|c|}{ Components } \\
\hline & 1 & 2 & 3 \\
\hline 1XWQX2 & 0.779 & & \\
\hline 1XWQX5 & 0.765 & & \\
\hline 1XWQX1 & 0.759 & & \\
\hline 1XWQX4 & 0.750 & & \\
\hline 1XWQX3 & 0.750 & & \\
\hline $1 \mathrm{RZ2}$ & & 0.877 & \\
\hline 1RZ3 & & 0.876 & \\
\hline $1 \mathrm{RZ1}$ & & 0.833 & \\
\hline 1QG1 & & & 0.866 \\
\hline 1QG3 & & & 0.842 \\
\hline 1QG2 & & & 0.840 \\
\hline
\end{tabular}

\subsubsection{Hypothesis testing (Table 4)}

One-way ANOVA is used to test the hypothesis of differences. The significance of the cognitive dimension is 0.371 , indicating that $\mathrm{H} 1 \mathrm{a}$ is not true. The significance of the emotional dimension is 0.000 , indicating that $\mathrm{H} 1 \mathrm{~b}$ is established. The significance of the dimension of behaviour tendency is 0.045 , indicating that $\mathrm{H} 1 \mathrm{c}$ is established. It can be concluded that $\mathrm{H} 1$ is established. 
Table 4. ANOVA test of brand story types on various factors

\begin{tabular}{|c|c|c|c|c|c|c|}
\hline \multirow{2}{*}{$\begin{array}{l}\text { Brand } \\
\text { story } \\
\text { type }\end{array}$} & \multicolumn{2}{|c|}{$\begin{array}{c}\text { Dimensio } \\
n \text { of } \\
\text { Cognition }\end{array}$} & \multicolumn{2}{|c|}{$\begin{array}{l}\text { Dimension of } \mathrm{E} \\
\text { motion }\end{array}$} & \multicolumn{2}{|c|}{$\begin{array}{c}\text { Dimension of Behavior } \\
\text { Tendency }\end{array}$} \\
\hline & $\begin{array}{c}\text { Mea } \\
n\end{array}$ & SD & Mean & SD & Mean & SD \\
\hline $\begin{array}{c}\text { Fictional } \\
\text { brand } \\
\text { story }\end{array}$ & 2.98 & $\begin{array}{c}1.16 \\
5\end{array}$ & 2.86 & 1.129 & 3.03 & 1.043 \\
\hline $\begin{array}{c}\text { Factual } \\
\text { brand } \\
\text { story }\end{array}$ & 3.08 & $\begin{array}{c}1.06 \\
5\end{array}$ & 3.28 & 1.053 & 3.23 & .892 \\
\hline $\mathrm{F}$ & $\begin{array}{c}0.80 \\
3\end{array}$ & & 14.799 & & 4.038 & \\
\hline $\begin{array}{c}\text { Significa } \\
\text { nce }\end{array}$ & $\begin{array}{c}0.37 \\
1\end{array}$ & & 0.000 & & 0.045 & \\
\hline
\end{tabular}

\section{CONCLUSION}

This article demonstrates the significant influence of the type of content expression of brand stories on brand attitudes. Through data analysis, it can be found that brand stories in different manifestations can obviously cause consumers to have different emotional resonance and connection with the brand due to their own vividness, visuality, and plot, affecting the brand's values or emotional output. Therefore, brands and consumers will interact with different degrees of emotions. Second, the different interactions between them will affect consumers' purchase intentions and behaviors. Finally, since both brand stories, as content carriers, can achieve their utility, better deliver product's and brand's information, and enable consumers to form more awareness about the brand, so the impact the type of content manifestation of brand stories exerts on cognitive dimension is not significant.

This article suggests that, in the brand marketing, brand managers can appropriately use the communication tool "brand story", pay attention to and explore the classification of brand stories, consider classifying brand stories based on the content manifestation, etc. of brand story, and choose brand stories' type reasonably in order to make a reasonable marketing plan, convey the brand culture, and achieve the purpose of enhancing the brand image and value more efficiently.

\section{REFERENCES}

[1] Rup Kumar Bikash, Gochhayat Jyotiranjan, Samanta Sasmita. Revisiting Brand Personality Attributes: Mediating Role of Brand Attitude, in: International Journal of Asian Business and Information Management (IJABIM), 2021, 12(2).

[2] Fischbach Sarah, Guerrero Veronica, Aaker J, Baumgartner H.et. Brand Stories: Transformative Learning Through Digital Brand Storytelling (DBS), in: Journal of Advertising Education, 2020, 24(2).

[3] Xu Man. The influence of brand story on brand attitude, in: Guangdong University of Foreign Studies, Guangzhou, 2020.

[4] Miri Rodriguez. Brand Storytelling: Put Customers at the Heart of Your Brand Story[M].Kogan Page:2019-01-28.

[5] Jia Yanrui. Research on the influence of brand stories on consumer attitudes, in: Xiamen University, Xiamen, 2017.

[6] Peng Chuanxin. Research on Brand Narrative Theory: The Construction and Dissemination of Brand Story, in: Wuhan University, Wuhan ,2011.

[7] Xu Lan, Zhao Shuangshuang, Cui Nan, etc. The influence of story design patterns on consumer brand attitudes, in: Management World, 2020, 36(10), pp.76-95.

[8] Zhao Bei, Jia Yanrui. A Review of Brand Story Research: Connotation, Composition and Function, in: Contemporary Finance, 2016(12), pp.65-76.

[9] Li Mengling. Research on the influence of brand stories under the Internet background on consumer brand attitudes, in: University of Electronic Science and Technology of China, Chengdu, 2020.

[10] Yuan Yue, Liu Li, Du Qinglong. Research on the influence of brand story on consumer self-brand connection, in: Consumer Economy, 2016, 32(06), pp.85-90. 